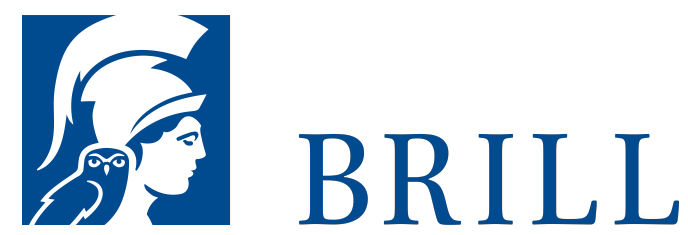

\title{
Kirchenmusikalisches Jahrbuch - 102. Jahrgang 2018
}

\section{Editor: Ulrich Konrad}

Das Kirchenmusikalische Jahrbuch bietet ein ökumenisches Forum für wissenschaftliche Studien zum weiten Feld der liturgischen, geistlichen und religiösen Musik vom Altertum bis zur Gegenwart.

Kirchenmusik im engsten Sinne als Musik zur Liturgie bis hin zu allen Formen religiöser Musik im weitesten Sinne umfasst ein kaum überschaubares Repertoire an Werken aus der kulturgeschichtlichen Spanne von der Antike bis zur Gegenwart. Das Kirchenmusikalische Jahrbuch erforscht dieses Repertoire jenseits konfessioneller Grenzen und zeigt sich offen für analytische, historische, philologische, soziologische, theologische und hermeneutische Methoden.

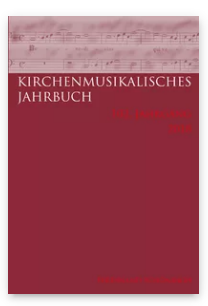

Pages: 122

Seiten, $40 \mathrm{~s} / \mathrm{w}$

Abb.

Language:

German

Subjects:

General,

Theology and

World

Christianity

Publisher: Brill |

Schöningh

Series:

Kirchenmusikalisches

Jahrbuch, Volume:

102

E-Book (PDF)

Released online:

11 Nov 2019

ISBN: 978-3-

657-70273-2

List price

Paperback

Publication date: o6 Sep 2019

ISBN: 978-35०6-70273-9

List price 
Biographical Note

Ulrich Konrad ist Professor am Institut für Musikforschung der Julius-Maximilians-Universität Würzburg.

For more information see brill.com

\begin{abstract}
Order information: Order online at brill.com
+44330 333 0049 | customerservices@brill.com

Submission information: brill.com/authors
\end{abstract}

Titles published by Brill | Fink, Brill | mentis or Brill | Schöningh:

+49(o)71 5413279216 | brill@brocom.de 